\title{
Resistance to Gummy Stem Blight in Melon (Cucumis melo L.) Germplasm and Inheritance of Resistance from Plant Introductions 157076, 420145, and 323498
}

\author{
Joseph N. Wolukau, Xiao-Hui Zhou, Ying Li, Yong-Bin Zhang, \\ and Jin-Feng Chen ${ }^{1}$ \\ State Key Laboratory of Crop Genetics and Germplasm Enhancement, \\ College of Horticulture, Nanjing Agricultural University, Nanjing 210095, \\ China
}

Additional index words. Cucumis melo, Didymella bryoniae, gummy stem blight, disease resistance, inheritance, single dominant gene

\begin{abstract}
Gummy stem blight incited by the fungus Didymella bryoniae is a major disease of melons worldwide. The objectives of the present study were to critically evaluate melon (Cucumis melo $\mathrm{L}$.) germplasm for resistance to $D$. bryoniae and to characterize the genetics of resistance in the resistant accessions. Two hundred sources of germplasm (plant introduction accessions, cultivars, breeding lines, landraces, and wild relatives) were screened against a single highly virulent isolate (IS25) of $D$. bryoniae in a plastic tunnel. The genetics of resistance to $D$. bryoniae was studied in three crosses between plant introductions 157076, 420145, and 323498, resistant parents that were fairly adapted (flowering, fruiting, powdery mildew tolerance) to Nanjing conditions, and plant introductions 268227, 136170, and NSL 30032 susceptible parents, respectively. Six populations of each cross (susceptible parent, resistant parent, $F_{1}, F_{2}$, the two reciprocal backcrosses) were analyzed for their responses to $D$. bryoniae. Seedlings in both studies were inoculated with a spore suspension $\left(5 \times 10^{5}\right.$ spores $\left./ \mathrm{mL}^{-1}\right)$ of $D$. bryoniae at the four to six true-leaf stages and assessed for leaf and stem damage at 7, 14, and $21 \mathrm{~d}$ postinoculation. Results of germplasm screening indicated most germplasms reported as resistant elsewhere were confirmed resistant under our conditions. However, some plant introductions identified as highly resistant elsewhere were susceptible under our conditions, the most interesting being plant introduction 482399. This plant introduction that was considered resistant was highly susceptible in our study. We also identified other sources of resistance not reported previously, for example, JF1; a wild Cucumis from the highlands of Kenya was rated highly resistant. Analysis of segregation of $F_{1}, F_{2}$, and backcross generations of the three crosses indicated that each of the three plant introductions carry a single dominant gene for resistance to the D. bryoniae.
\end{abstract}

Melon production is severely constrained by several soil-borne disease pathogens. Of these pathogens, Didymella bryoniae (Auersw), Rehm that causes gummy stem blight (GSB) is one of the most destructive resulting in substantial economic losses (Bruton, 1998; Crosby et al., 2002; Frantz and Jahn, 2004; McCreight, 2002; Wako et al., 2002). The pathogen attacks and inflicts heavy losses in quality and yield in several other genera of the cuburbitaceae worldwide, e.g., squash (Cucurbita L.) (Zitter and Kyle, 1992), cucumber (Cucumis L.) in the United States (Gusmini and Wehner, 2002; St. Amand and Wehner, 1991) and on water-

\footnotetext{
Received for publication 29 July 2007. Accepted for publication 2 Nov. 2006.

This study was partially supported by program no. 2005-2007 from the Jiangsu Natural Science Foundation.

${ }^{1}$ To whom reprint requests should be addressed; e-mail jfchen@njau.edu.cn.
}

melon (Citrullus Neck.) (Keinath et al., 1995). The disease has also been reported in Europe (Frantz and Jahn, 2004; van Steekelenburg, 1985), Asia (Wako et al., 2002), and elsewhere (Bruton, 1998).

Although chemical control has had great success, repeated use of fungicides is not advisable as a long-term solution as a result of the negative impact of pesticides in the environment. Moreover, development of resistance to some systemic benzimidazole fungicides in $D$. bryoniae from several cucurbit production areas has been reported (Kato et al., 1984; Keinath and Zitter, 1998; Malathrokis and Vokalounakis, 1983). Crop rotations are only partially effective; wind and other agents can easily bring in new inoculum to start new infections (Tullu et al., 2002). This illustrates the necessity to use host resistance in conjunction with good cultural practices and judicial use of fungicides. Use of resistant cultivars is the most strategic, environmentally friendly, accepted, and economic means of GSB management (Vokalounakis, 1993; 1995; Wehner and St. Amand, 1993).

Several greenhouse, plastic tunnel, and field evaluations were previously conducted to identify sources of resistance to D. bryoniae. A limited amount of resistance was reported in some cultigens. Sowell et al. (1966) tested over 1000 accessions of melon and reported resistance in plant introduction 140471 to be near immunity. On the contrary, McGrath et al. (1993) contends no sufficient resistance to GSB is available in melon. Furthermore, resistance in plant introduction 140471 has recently been described as variable (Tsutsumi and da Silva, 2004) or not effective at all (Takada, 1983). Several other sources of resistance to gummy stem blight in melon have been reported over the years (McGrath et al., 1993; Sakata et al., 2000; Sowell, 1981; Takada, 1983; Tsutsumi and da Silva, 2004; Zhang et al., 1997). Zhang et al. (1997) found plant introductions $157076,157080,157081,157082$, 157084, 482393, 482398, 482399, 482402, 482403, 482408,255478 , and 511890 to be as good as plant introduction 140471.

Most GSB-resistant melon varieties and breeding lines released to date derive resistance from plant introduction 140471 (McGrath et al., 1993; Norton, 1971, 1972; Norton and Cosper, 1989; Norton et al., 1985; Sowell, 1981). However, plant introduction 140471 has failed to provide sufficient resistance (e.g., Sitterly and Keinath, 1996; Zhang et al., 1997). Moreover, plant introduction 140471 was been reported to be ineffective against a Japanese isolate of $D$. bryoniae (Sakata et al., 2000; Takada, 1983). Zhang et al. (1997) also reported resistance derived from plant introduction 140471 appears to diminish when deployed into commercial, large-fruited varieties. There is still interest in developing melon varieties with higher GSB resistance than existing ones; hence, new sources of resistance should be sought and validated. New sources of resistance will be useful in melon production areas where existing sources of resistance are not effective.

Information on the genetics of resistance to the GSB pathogen in most melon cultigens reported as resistant is limited (Pitrat et al., 1998). Two genetic systems have been proposed, monogenic-dominant and monogenicrecessive. One dominant gene $(M c)$ confers high resistance to GSB in plant introduction 140471 (Prasad and Norton, 1967; Sowell et al., 1966); another gene, $M c-2$, controlling an intermediate level of resistance in breeding lines C- 1 and C-8, was reported by Prasad and Norton (1967). Frantz and Jahn (2004) confirmed the monogenic-dominant status of $M c$ in plant introduction 140471. Plant introduction 157082 and 511890 were both reported to carry monogenic-dominant genes for GSB resistance, whereas resistance in plant introduction 482399 was monogenicrecessive (Frantz and Jahn, 2004; Zuniga et al., 1999). Frantz and Jahn (2004) reported a monogenic dominant gene for GSB resistance in plant introduction 482398 . The genes 
in plant introductions 140471, 157082 , 511890, 482498, and 482399 were renamed $G s b-1, G s b-2, G s b-3, G s b-4$, and $g s b-5$, respectively (Frantz and Jahn, 2004). The five genes are independent of each other (Frantz and Jahn, 2004). Resistance in a sixth accession, Jmu-15 (C melo var. agrestis), is conferred by incomplete dominant gene(s) (Wako et al., 2002). However, allelism in this accession has not been verified nor has the gene(s) been named. The genetics of resistance and allelic relationships of most melon plant introductions reported as resistant to GSB is still unknown, incomplete, or has not been verified, e.g., in plant introductions 296345, 266935, 436533, 157076, and others. Knowledge of the genetic basis of resistance to $D$. bryoniae is essential for the efficient development of resistant melon cultivars. The evaluation, reevaluation, crossing, and backcrossing processes can be time-consuming and tedious. Often because the genetics of resistance of resistant genotypes are unknown, the introgression process becomes one of trial and error. There is need, therefore, to determine the mode of inheritance to the GSB pathogen in other sources and possibly establish if these sources of resistance share the same genetic factors.

The objectives of the present study were: 1) to critically examine the resistance of melon germplasm to D. bryoniae and 2) to characterize the genetics of resistance in plant introductions 157076, 420145, and 323498. These plant introductions were confirmed to be highly resistant to $D$. bryoniae and are fairly well adapted to Nanjing conditions.

\section{Materials and Methods}

Germplasm for gummy stem blight screening. Two hundred accessions originating from 42 countries were chosen based on a diversity of characteristics for screening. Accessions included landraces and commercial varieties of melo, reticulatus, muskmelon, inodorus, conomon, and agrestis groups; wild cucumis species; and other cucurbits, mainly watermelon (Citrullus spp.). Test accessions consisted of those reported elsewhere as resistant/susceptible to D. bryoniae and those of unknown reaction (including a new collection, e.g., JF1). Seed of the accessions were obtained from North Central Regional Center for Genetic resources Preservation, Ames, Iowa. Other accessions were donated by Ming-Zhu Wu (China), Liz MakokhaWolukau (Kenya), or from market/farm collections in Nanjing, China.

Population development for genetic analysis of resistance. The genetics of resistance to $D$. bryoniae in melon was studied using three $\mathrm{F}_{2}$ populations of crosses between plant introduction 268227 (a susceptible parent) and plant introduction 157076 (a resistant parent); between plant introduction 136170 (susceptible parent) and plant introduction 420145 (resistant parent); and between NSL 30032 (susceptible) and plant introduction 323498 (resistant), $F_{1}$ hybrids, reciprocal backcrosses, and the parents. Plant introduction 157076 is an accession from China, whereas plant introduction 268227 is a highly susceptible accession from Iran. Plant introduction 420145 is a resistant accession from Japan, whereas the highly susceptible plant introduction 136170 is from Italy. Similarly, plant introduction 323498 is originally from China, whereas the susceptible parent is a commercial cultivar ('Top Mark') from the United States. All crosses were made by controlled pollination in a plastic tunnel, Nanjing, China. The North Central Regional Center for Genetic resources Preservation, Iowa, provided all seeds for the parents used in this study.

Inoculum preparation. The inoculum was prepared based on the method of Kwon et al. (1997) with modifications. Spore isolates of $D$. bryoniae were obtained from diseased melon plant materials in plastic tunnels in Qi ling, Nanjing, China. The isolate, named IS25, was increased on potato dextrose agar (e.g., Gusmini et al., 2003; Kwon et al., 1997) in petri plates $(150 \mathrm{~cm} \times 30 \mathrm{~cm})$ using mycelial plug inoculation. Petri plates were incubated at $25^{\circ} \mathrm{C}$ in the dark for $7 \mathrm{~d}$ followed by ultraviolet irradiation $\left(40 \mathrm{w}, 12 \mathrm{~h} \cdot \mathrm{d}^{-1}\right)$ for $4 \mathrm{~d}$ at the same temperature. These conditions were conducive for the formation of sporeproducing pycinidia. Inoculum was prepared by flooding the plates with 5 to $10 \mathrm{~mL}$ of acidified distilled water and scraping the surface of the agar with an L-shaped glass rod. The solution was acidified to $\mathrm{pH} 4.0$ using lactic acid containing 20 drops per $\mathrm{L}$ of Tween-20 as surfactant. Low $\mathrm{pH}$ and surfactant increase spore discharge from pycinidia, prevent spore agglutination, and aid adhesion of spores to leaf and stem surfaces, respectively. The liquid from each plate was filtered through four layers of cheesecloth to remove mycelia, pycinidia, and dislodged agar. The spore suspension was adjusted to $\approx 5 \times 10^{5}$ spores $\cdot \mathrm{ml}^{-1}$ using a hemacytometer.

Plant culture. Resistance evaluation in the plastic house was conducted according to Zhang et al. (1997) with slight modifications. Briefly, seeds were wrapped in muslin cloth, surface-sterilized in warm water at $50{ }^{\circ} \mathrm{C}$ for $15 \mathrm{~min}$, transferred to water at room temperature for $4 \mathrm{~h}$, and then incubated at $28^{\circ} \mathrm{C}$ for $2 \mathrm{~d}$ after draining off excess water. Uniformly germinated seedlings were transplanted into $12 \mathrm{~cm} \times 13-\mathrm{cm}$ plastic pots filled with sand, soil, and vermiculite at the ratio of $1: 1: 1$. For the screening study, six to seven seedlings were planted in each replication with two replications per accession. Resistant and susceptible accessions were placed randomly among the pots as disease severity checks and to aid in disease spread. Seedlings were maintained in the plastic tunnel at $27^{\circ} \mathrm{C} \pm 2$. Plants were fertilized weekly with a dilute solution of soluble $\mathrm{N}-\mathrm{P}-\mathrm{K}$ fertilizer, $1 \mathrm{~N}-$ $1.5 \mathrm{P}-1.0 \mathrm{~K}$ per $10 \mathrm{~L}$ of water.

Inoculation. Plants at the four to six trueleaf stage (3-4 weeks old) were sprayed with spore suspension to near runoff. Inoculation was done in the morning or late evening. Plants were watered $1 \mathrm{~d}$ before inoculation and $3 \mathrm{~d}$ after inoculation to encourage uniform disease development and spread of the inoculum. Additionally, plants were finemisted on day 2 postinoculation to provide free water on the leaf surfaces. After inoculation, plants were enclosed in a tight plastic tent within the plastic tunnel to maintain high relative humidity $(92 \%)$. The clear plastic tent was removed $3 \mathrm{~d}$ after inoculation. A dry and wet bulb thermometer was suspended inside the tent to monitor the level of humidity. For the GSB screening experiment, plants were reinoculated $7 \mathrm{~d}$ after the first inoculation to ensure there were no escapees or false-positives.

Data collection, analysis and interpretation. Disease ratings were scored according to the methods described in Zhang et al. (1997) and Zuniga et al. (1999) with slight modifications. Visual ratings on leaf and stem were scored at 7,14 , and 21 d postinoculation on the following scales: leaf, $1=$ $0 \%$ of leaf area affected, $2=\geq 25 \%$ leaf area affected, $3=\geq 25 \% \leq 50 \%$ leaf area affected, $4=\geq 50 \% \leq 75 \%$ leaf area affected, $5=$ $\geq 75 \% \leq 100 \%$ leaf area affected; stem: $1=$ no damage, $2=$ single lesion 1 to $10 \mathrm{~mm}$ long or composite lesions 1 to $20 \mathrm{~mm}$ long, stem not girdled, $3=$ lesion 21 to $80 \mathrm{~mm}$ long or girdling of stem, $4=$ stem withered, and $5=$ seedling dead. For the screening study, analysis of variance on disease score ratings was done using GLM procedures of SAS (SAS Institute, Cary, N.C.). Phenotypic correlations between leaf and stem resistance were also calculated using CORR procedure of SAS, and the coefficient of simple correlation (r) was determined.

For the genetics of resistance, only stem score ratings were analyzed. Classification of segregating progenies is most reliable when based on stem damage ratings in which resistant individuals score 1 or 2 and susceptible plants score 3 to 5 (Zhang et al., 1997; Zuniga et al., 1999). The number of individuals falling in resistant (stem damage rating 1-2) and susceptible (stem damage ratings 3-5) categories was determined in of each segregating population. The resulting ratios were tested for goodness-of-fit using $\chi^{2}$ analysis.

\section{Results}

Screening for resistance to gummy stem blight. We ranked the accessions for GSB resistance based on the mean of three ratings of two replications for leaf and stem (Table 1). Data (Table 1) indicate most germplasm reported highly resistant, including plant introduction 140471, were consistently resistant under our conditions. Other plant introductions previously reported resistant (Zhang et al., 1997) and also highly rated resistant in our study included plant introductions 157076 (which was entered two times), 157082, 323498, and 436534. All the wild relatives were rated highly resistant with a rating of 1.0 for stem and 1.0 to 1.5 for leaf. A new wild accession, JF1 (Cucumis spp.) collected from the highlands of Kenya was 
Table 1. Foliar and stem disease indices for Cucumis melo L. (unless specified) germplasm in response to D. bryoniae inoculation from a plastic house screen.

\begin{tabular}{|c|c|c|c|c|}
\hline \multirow[b]{2}{*}{ Accession } & \multirow[b]{2}{*}{ Origin } & \multirow[b]{2}{*}{ Hort $^{2}$ group } & \multicolumn{2}{|c|}{ Disease rating $^{\mathrm{y}}$} \\
\hline & & & Leaf & Stem \\
\hline$\overline{\mathrm{P} 1}$ & Kenya & Cucumis & 1.0 & 1.0 \\
\hline PI 364472 & S. Africa & C.zeyheri & 1.0 & 1.0 \\
\hline PI 255478 & Korea & melo & 1.1 & 1.0 \\
\hline $\mathrm{JF} 1$ & Kenya & Cucumis & 1.1 & 1.0 \\
\hline Jinguan & China & Thins $^{\mathrm{w}}$ & 1.2 & 1.0 \\
\hline PI 420147 & Japan & melo & 1.2 & 1.0 \\
\hline Ames 26709 & USA & texanus & 1.2 & 1.0 \\
\hline PI 299571 & S. Africa & C. africanus & 1.2 & 1.0 \\
\hline PI 196477 & Brazil & C. anguria & 1.2 & 1.0 \\
\hline PI 618834 & China & melo & 1.3 & 1.0 \\
\hline Ames 26695 & Mexico & texanus & 1.3 & 1.0 \\
\hline PI200819 & Myanmar & melo & 1.3 & 1.0 \\
\hline $\mathrm{M} 2 \mathrm{~K}$ & Kenya & C. lanatus & 1.4 & 1.0 \\
\hline PI 299570 & S. Africa & Cucumis & 1.4 & 1.0 \\
\hline PI 196477 & Brazil & C. anguria & 1.5 & 1.0 \\
\hline Ames 26737 & USA & texanus & 1.5 & 1.0 \\
\hline PI 482409 & Zimbabwe & melo & 1.5 & 1.0 \\
\hline PI 482402 & Zimbabwe & melo & 1.5 & 1.0 \\
\hline PI 164797 & India & melo & 1.5 & 1.0 \\
\hline C. figarei & Kenya & Cucumis & 1.5 & 1.0 \\
\hline PI 436534 & Senegal & melo & 1.6 & 1.0 \\
\hline PI 157076 & China & melo & 2.0 & 1.0 \\
\hline XinmiZa9 & China & Thicks ${ }^{\mathrm{v}}$ & 1.1 & 1.1 \\
\hline PI 200819 & Myanmar & melo & 1.3 & 1.1 \\
\hline Ames 26698 & USA & texanus & 1.3 & 1.1 \\
\hline Ames 26729 & USA & texanus & 1.3 & 1.1 \\
\hline PI 321004 & Taiwan & melo & 1.4 & 1.1 \\
\hline Ames 26707 & USA & melo & 1.4 & 1.1 \\
\hline L8K & Kenya & C. lanatus & 1.6 & 1.1 \\
\hline PI 183311 & India & melo & 1.7 & 1.1 \\
\hline PI 420177 & Japan & melo & 1.7 & 1.1 \\
\hline PI 266933 & Japan & melo & 1.7 & 1.1 \\
\hline PI 140471 & USA & melo & 1.8 & 1.1 \\
\hline PI 470253 & Indonesia & melo & 1.2 & 1.2 \\
\hline PI 185111 & Ghana & melo & 1.5 & 1.2 \\
\hline NJG6 & China & Thins ${ }^{\mathrm{w}}$ & 1.5 & 1.2 \\
\hline PI 500362 & Zambia & melo & 1.6 & 1.2 \\
\hline PI 420145 & Japan & melo & 1.8 & 1.2 \\
\hline PI 489689 & Mexico & melo & 2.2 & 1.2 \\
\hline PI 511890 & Mexico & melo & 1.4 & 1.3 \\
\hline M3SA & S. Africa & C. lanatus & 1.5 & 1.3 \\
\hline PI 435345 & Mexico & melo & 1.7 & 1.3 \\
\hline NJG1 & China & Thins $^{\mathrm{w}}$ & 1.8 & 1.3 \\
\hline M1K & Kenya & C. lanatus & 2.5 & 1.3 \\
\hline PI 292190 & S. Africa & C. metuliferus & 1.5 & 1.4 \\
\hline PI 505601 & Zambia & melo & 1.6 & 1.4 \\
\hline PI 500600 & Zambia & melo & 1.7 & 1.4 \\
\hline PI 505599 & Zambia & melo & 1.8 & 1.4 \\
\hline PI 403994 & Colombia & melo & 1.8 & 1.4 \\
\hline PI 292190 & S. Africa & C. metuliferus & 1.5 & 1.4 \\
\hline PI 157070 & China & melo & 2.1 & 1.4 \\
\hline PI 438680 & Mexico & melo & 2.2 & 1.4 \\
\hline PI 157071 & China & melo & 1.6 & 1.5 \\
\hline PI 323499 & China & melo & 1.9 & 1.5 \\
\hline PI 420150 & China & conomon & 1.9 & 1.5 \\
\hline PI 157076 & China & melo & 2.0 & 1.5 \\
\hline PI 420149 & USA & conomon & 2.2 & 1.5 \\
\hline PI 618832 & China & melo & 1.5 & 1.6 \\
\hline L4K & Kenya & muskmelon & 1.8 & 1.6 \\
\hline PI 323498 & China & melo & 2.0 & 1.6 \\
\hline PI 161375 & Korea & melo & 2.2 & 1.6 \\
\hline PI 482410 & Zimbabwe & melo & 2.0 & 1.7 \\
\hline PI 532829 & China & melo & 2.0 & 1.8 \\
\hline PI 157082 & China & melo & 2.0 & 1.8 \\
\hline PI 244713 & USA & melo & 2.3 & 1.8 \\
\hline $\mathrm{L} 5 \mathrm{~K}$ & Kenya & C. lanatus & 3.0 & 1.8 \\
\hline PI 481479 & Zimbabwe & melo & 3.2 & 1.8 \\
\hline PI 295341 & Australia & melo & 2.2 & 1.9 \\
\hline PI 505602 & Zambia & melo & 2.4 & 1.9 \\
\hline PI 482424 & Zimbabwe & melo & 2.5 & 1.9 \\
\hline PI 420176 & Japan & melo & 2.3 & 2.0 \\
\hline PI 183228 & Egypt & melo & 2.4 & 2.0 \\
\hline
\end{tabular}

(Continued on next page) also rated 1.0. Some accessions rated highly resistant previously in the United States and elsewhere (e.g., Zhang et al., 1997) were not resistant under our conditions, the most interesting being plant introduction 482399 from Zimbabwe. Other accessions that behaved similarly were plant introductions 190554 (Iraq), 183221 (Egypt), and 183226 (Egypt). On the other hand, some accessions reported as highly susceptible were rated highly resistant in our study, e.g., plant introductions 532829 (China), 185111 (Ghana), 200819 (Myanmar), and 500362 (Zambia). Most of the Chinese commercial germplasm were highly susceptible, e.g., 'Huanghemi' (stem rating 4.63), 'Jiashi' (stem rating 3.62), and 'Lubaoshi' (stem rating 3.6). However, 'Jinguan', a thin skin melon, and 'Xin mi Za9', a hemitype melon, were rated highly resistant, with stem scores of 1.0 and 1.12, respectively. The landrace collections from farms, NJG1 and NJG6, were highly resistant, having mean stem scores of 1.3 and 1.2, respectively. Most of the commercial melon (C. melo) and watermelon (Citrullus lanatus) accessions from Kenya and South Africa were rated highly to moderately resistant (stem rating 1.02.25), except L7K (3.08), a muskmelon type melon from Kenya, and M4SA (2.89), a watermelon from South Africa, were susceptible. No resistance was observed in C. melo var. flexuous and inodorus accessions in our study (Table 1). Generally leaf resistances were slightly higher than stem resistances, but leaf and stem resistance were highly correlated $\left(\mathrm{r}=0.97, P_{\propto}=0.05\right)$ (Table 1). However, in a few cases, some of the germplasm showed leaf resistance that was at par with stem resistance or higher like in the case of plant introductions 614174,255478 , and XinminZa9 (Table 1).

Genetics of resistance. Several of the highly resistant $C$. melo plant introductions (from previous work and our data) that appeared well adapted to our conditions (flowering, fruiting, powdery mildew tolerance) were crossed with susceptible parents to generate $F_{1}, F_{2}$, and reciprocal backcross populations to characterize their genetics of resistance. The most adaptable of these and with potential for breeding into commercial cultivars were plant introductions 157076, 420145, and 323498. Plant introductions 157076 and 323498 are of local Chinese origin and could have useful genes of breeding value.

The susceptible and resistant checks (Table 2) responded consistently after inoculation with the $D$. bryoniae spore suspension. The susceptible checks, e.g., 'Huanghemi', developed leaf and stem lesions uniformly within 6 to $7 \mathrm{~d}$ of inoculation, whereas plants of plant introduction 196477, a resistant wild Cucumis from Brazil, were uniformly rated highly resistant. This confirmed the virulence of isolate IS25 and showed the screening procedure was sensitive and valid.

Inheritance of resistance to Didymella bryoniae in plant introduction 157076. The 
Table 1. (continued) Foliar and stem disease indices for Cucumis melo L. (unless specified) germplasm in response to $D$. bryoniae inoculation from a plastic house screen.

\begin{tabular}{|c|c|c|c|c|}
\hline \multirow[b]{2}{*}{ Accession } & \multirow[b]{2}{*}{ Origin } & \multirow[b]{2}{*}{ Hort $^{2}$ group } & \multicolumn{2}{|c|}{ Disease rating ${ }^{y}$} \\
\hline & & & Leaf & Stem \\
\hline PI 505603 & Zambia & melo & 2.6 & 2.0 \\
\hline PI 476332 & Russian Fed. ${ }^{\mathrm{x}}$ & melo & 2.8 & 2.1 \\
\hline PI 266949 & France & muskmelon & 3.4 & 2.1 \\
\hline L3K & Kenya & C. lanatus & 2.1 & 2.2 \\
\hline PI 482394 & Zimbabwe & melo & 2.6 & 2.2 \\
\hline PI 436533 & Senegal & melo & 2.1 & 2.3 \\
\hline PI 381773 & India & melo & 2.6 & 2.3 \\
\hline PI 200816 & Myanmar & melo & 2.7 & 2.3 \\
\hline L6K & Kenya & muskmelon & 2.8 & 2.3 \\
\hline PI 512438 & Spain & melo & 2.9 & 2.3 \\
\hline PI 266945 & Japan & muskmelon & 3.0 & 2.3 \\
\hline PI 614174 & India & agrestis & 1.9 & 2.4 \\
\hline PI 164493 & India & melo & 2.5 & 2.4 \\
\hline Ames 8578 & USA & melo & 2.6 & 2.4 \\
\hline PI 164364 & Pakistan & melo & 2.5 & 2.5 \\
\hline PI 255946 & Germany & melo & 3.2 & 2.5 \\
\hline PI 614494 & India & agrestis & 2.8 & 2.6 \\
\hline PI 482397 & Zimbabwe & melo & 2.8 & 2.6 \\
\hline PI 482395 & Zimbabwe & melo & 2.8 & 2.6 \\
\hline PI 123501 & India & melo & 3.0 & 2.6 \\
\hline NJG7 & China & $\mathrm{NA}^{\mathrm{u}}$ & 2.4 & 2.7 \\
\hline PI 255950 & Greece & muskmelon & 3.2 & 2.7 \\
\hline PI 818837 & China & melo & 2.9 & 2.8 \\
\hline Xiaojinli & China & Thicks $^{\mathrm{w}}$ & 3.3 & 2.8 \\
\hline M4SA & S. Africa & C. lanatus & 2.7 & 2.9 \\
\hline PI 211116 & Israel & melo & 3.1 & 2.9 \\
\hline PI 436532 & Senegal & melo & 2.6 & 3.0 \\
\hline Yindi & China & $\mathrm{NA}^{\mathrm{u}}$ & 2.8 & 3.0 \\
\hline PI 234607 & S. Africa & melo & 3.3 & 3.0 \\
\hline PI 262169 & France & melo & 3.4 & 3.0 \\
\hline PI 169329 & Turkey & melo & 3.5 & 3.0 \\
\hline PI 318653 & USA & melo & 3.6 & 3.0 \\
\hline Ames 13330 & Spain & melo & 4.1 & 3.0 \\
\hline Ames 18738 & USA & melo & 4.3 & 3.0 \\
\hline Lubaoshi & China & Thicks $^{\mathrm{v}}$ & 2.4 & 3.1 \\
\hline PI 282448 & S. Africa & melo & 2.9 & 3.1 \\
\hline Ames 13312 & Spain & melo & 3.1 & 3.1 \\
\hline Ames 20219 & USA & melo & 3.3 & 3.1 \\
\hline L7K & Kenya & muskmelon & 3.4 & 3.1 \\
\hline PI 164487 & India & melo & 3.5 & 3.1 \\
\hline PI 614189 & India & melo & 3.2 & 3.2 \\
\hline PI 614196 & India & melo & 3.3 & 3.2 \\
\hline PI 512539 & Spain & melo & 3.0 & 3.3 \\
\hline PI 304745 & El Salvador & melo & 3.4 & 3.3 \\
\hline PI 268227 & Iran & melo & 3.6 & 3.3 \\
\hline PI 183223 & Egypt & melo & 3.8 & 3.3 \\
\hline PI 438686 & Mexico & melo & 3.8 & 3.3 \\
\hline Ames & 13259 & melo & 4.1 & 3.3 \\
\hline PI 512538 & Spain & melo & 3.4 & 3.4 \\
\hline PI 193495 & Ethiopia & melo & 3.5 & 3.4 \\
\hline PI 251778 & Former USSR & melo & 3.5 & 3.4 \\
\hline PI 525116 & Egypt & melo & 3.7 & 3.4 \\
\hline Ames 13325 & Spain & melo & 3.7 & 3.4 \\
\hline PI 136229 & Canada & melo & 3.8 & 3.4 \\
\hline NSL 30032 & USA & melo & 3.1 & 3.5 \\
\hline Ames 2831 & USA & melo & 3.5 & 3.5 \\
\hline PI 438685 & Mexico & melo & 3.4 & 3.6 \\
\hline PI 183222 & Egypt & melo & 3.5 & 3.6 \\
\hline Jiashi & China & Thicks ${ }^{v}$ & 3.6 & 3.6 \\
\hline PI 482399 & Zimbabwe & melo & 3.8 & 3.6 \\
\hline PI 507873 & Hungary & melo & 4.0 & 3.7 \\
\hline PI 385966 & Kenya & melo & 4.0 & 3.8 \\
\hline PI 124112 & India & melo & 4.1 & 3.8 \\
\hline PI 183221 & Egypt & melo & 4.1 & 3.8 \\
\hline PI 255952 & USA & muskmelon & 4.1 & 3.8 \\
\hline PI 136170 & Italy & melo & 4.2 & 3.8 \\
\hline PI 525125 & Egypt & melo & 4.3 & 3.8 \\
\hline PI 255949 & Greece & inodorus & 4.8 & 3.8 \\
\hline PI 525149 & Egypt & flexuosus & 3.6 & 3.9 \\
\hline Ames 2829 & USA & melo & 4.1 & 3.7 \\
\hline PI 255953 & USA & muskmelon & 4.1 & 3.7 \\
\hline PI 164723 & India & melo & 4.1 & 3.7 \\
\hline
\end{tabular}

(Continued on next page) parents (plant introduction 268227, plant introduction 157076), the $\mathrm{F}_{1}$, the plant introduction $268227 \times$ plant introduction 157076 , and the backcrosses were evaluated and analyzed for response to $D$. bryoniae inoculation (Table 3) to determine the inheritance of resistance. All the plants of plant introduction 268227, the susceptible parent, developed GSB symptoms uniformly and most of them died within 2 weeks of inoculation. On the other hand, plant introduction 157076 was completely resistant with a mean stem rating of 1.3 except for plant number 1 , which had superficial lesions and later died. This plant bordered another GSB screening experiment and may have received a higher dose of inoculum than the rest of the plants. All the 64 (plant introduction $268227 \times$ plant introduction 157076) $F_{1}$ plants had an average rating of 1.4 except plant number 59 , which, like in the case of plant number 1 of plant introduction 157076, was rated 3 for similar reasons described previously. $\mathrm{F}_{2}$ segregation agreed with three resistant to one susceptible ratio, consistent with a monogenic dominant mode of resistance. The backcross to the susceptible parent (plant introduction $268227 \times$ plant introduction $157076) \times$ plant introduction 268227 segregated with a one resistant to one susceptible ratio, whereas the backcross to the resistant parent [(plant introduction $268227 \times$ plant introduction 157076) $\times$ plant introduction 268227] segregated one resistant to zero susceptible.

Inheritance of resistance to Didymella bryoniae in plant introduction 420145. The responses of $F_{1}, F_{2}$, and backcross plants of plant introduction $136170 \times$ plant introduction 420145 were analyzed and results are presented in Table 3. The $\mathrm{F}_{1}$ plants were all resistant, whereas the $\mathrm{F}_{2}$ plants segregated consistent with the three resistant to one susceptible ratio, indicating a dominant gene. The backcross population (plant introduction $136170 \times$ plant introduction 420145$) \times$ plant introduction 136170 segregated one resistant to one susceptible, whereas the backcross population (plant introduction $136170 \times$ plant introduction 420145$) \times$ plant introduction 420145 segregated one resistant to zero susceptible, further suggesting a single dominant gene is involved. Overall, the data indicate that resistance to GSB in accession plant introduction 420145 is conditioned by a single dominant gene.

Inheritance of Didymella bryoniae resistance in plant introduction 323498 . All the $\mathrm{F}_{1}$ plants from plant introduction $323498 \times$ NSL 30032 cross were resistant to the D. bryoniae spore inoculation (Table 3 ). Segregation for resistance in the $F_{2}$ population revealed a three resistant to one susceptible ratio $\left(\chi^{2}=0.31\right)$, whereas the backcross to the susceptible parent, NSL 30032 gave a good fit to a $1: 1$ ratio $\left(\chi^{2}=0.73\right)$. The parents plant introduction 323498 and NSL 30032 were all uniformly resistant and susceptible respectively except plant number 11 of the resistant parent, which was rated 3; the reasons for this have been described previously. These 
Table 1. (continued) Foliar and stem disease indices for Cucumis melo L. (unless specified) germplasm in response to $D$. bryoniae inoculation from a plastic house screen.

\begin{tabular}{|c|c|c|c|c|}
\hline \multirow[b]{2}{*}{ Accession } & \multirow[b]{2}{*}{ Origin } & \multirow[b]{2}{*}{ Hort $^{\mathrm{z}}$ group } & \multicolumn{2}{|c|}{ Disease rating $^{\mathrm{y}}$} \\
\hline & & & Leaf & Stem \\
\hline$\overline{\text { PI } 414723}$ & India & melo & 3.8 & 3.8 \\
\hline PI 512494 & Spain & melo & 4.0 & 3.9 \\
\hline Ames 2830 & USA & melo & 3.6 & 4.0 \\
\hline PI 313970 & India & melo & 4.0 & 4.0 \\
\hline PI 512532 & Spain & melo & 4.2 & 4.0 \\
\hline PI 512540 & Spain & melo & 4.3 & 4.0 \\
\hline PI 439744 & Iran & melo & 4.3 & 4.0 \\
\hline PI 230185 & Iran & melo & 4.3 & 4.0 \\
\hline PI 229807 & USA & melo & 4.4 & 4.0 \\
\hline PI 525138 & Egypt & flexuosus & 4.0 & 4.1 \\
\hline PI 260651 & Afghanistan & melo & 4.1 & 4.1 \\
\hline PI 512535 & Spain & melo & 4.4 & 4.1 \\
\hline PI 512447 & Spain & melo & 4.4 & 4.1 \\
\hline PI 194056 & China & melo & 4.5 & 4.1 \\
\hline PI 183307 & India & melo & 4.4 & 4.1 \\
\hline PI 512508 & Spain & melo & 4.8 & 4.1 \\
\hline PI 183226 & Egypt & melo & 4.0 & 4.2 \\
\hline PI 296118 & Egypt & melo & 4.3 & 4.2 \\
\hline PI 197891 & USA & melo & 4.3 & 4.2 \\
\hline PI 181875 & Syria & melo & 4.4 & 4.2 \\
\hline PI 512533 & Spain & melo & 4.4 & 4.2 \\
\hline PI 525115 & Egypt & melo & 4.5 & 4.2 \\
\hline PI 324525 & Afghanistan & melo & 4.5 & 4.2 \\
\hline PI 175676 & Turkey & melo & 4.7 & 4.2 \\
\hline PI 525141 & Egypt & flexuosus & 4.0 & 4.3 \\
\hline PI 525144 & Egypt & flexuosus & 4.4 & 4.3 \\
\hline PI 124440 & India & melo & 4.5 & 4.4 \\
\hline PI 512448 & Spain & melo & 4.6 & 4.4 \\
\hline PI 174156 & Turkey & melo & 4.6 & 4.4 \\
\hline PI 194052 & China & melo & 4.6 & 4.4 \\
\hline PI 420152 & Afghanistan & inodorus & 4.7 & 4.4 \\
\hline PI 357791 & Yugoslavia & melo & 4.9 & 4.4 \\
\hline Ames 2822 & USA & melo & 4.4 & 4.5 \\
\hline PI 167057 & Turkey & melo & 4.5 & 4.5 \\
\hline PI 525146 & Egypt & flexuosus & 4.7 & 4.5 \\
\hline PI 418768 & Afghanistan & melo & 4.7 & 4.5 \\
\hline PI 512530 & Spain & melo & 4.8 & 4.5 \\
\hline PI 525128 & Egypt & melo & 4.5 & 4.5 \\
\hline PI 204304 & Afghanistan & melo & 4.6 & 4.6 \\
\hline PI 525135 & Egypt & flexuosus & 4.6 & 4.6 \\
\hline PI 435086 & China & melo & 4.8 & 4.6 \\
\hline Huanghemi & China & $\mathrm{NA}^{\mathrm{u}}$ & 4.8 & 4.6 \\
\hline PI 344431 & Iran & melo & 4.8 & 4.6 \\
\hline PI 319214 & Egypt & melo & 4.6 & 4.7 \\
\hline PI 512534 & Spain & melo & 4.6 & 4.7 \\
\hline PI 140632 & Iran & melo & 4.7 & 4.7 \\
\hline PI 313976 & Uzebekistan & melo & 4.8 & 4.7 \\
\hline PI 124111 & India & melo & 4.8 & 4.7 \\
\hline Ames 13301 & Spain & melo & 4.6 & 4.8 \\
\hline PI 154339 & China & melo & 4.8 & 4.8 \\
\hline PI 255949 & Greece & inodorus & 4.8 & 4.8 \\
\hline PI 319218 & Egypt & melo & 5.0 & 4.8 \\
\hline PI 271267 & Iran & melo & 4.9 & 4.9 \\
\hline PI 212210 & Greece & melo & 5.0 & 4.9 \\
\hline PI 190554 & Iraq & melo & 5.0 & 4.9 \\
\hline PI 306136 & Iran & melo & 5.0 & 5.0 \\
\hline PI 618837 & China & melo & 5.0 & 5.0 \\
\hline PI 296385 & Iran & melo & 5.0 & 5.0 \\
\hline PI 288233 & Egypt & melo & 5.0 & 5.0 \\
\hline
\end{tabular}

Standard deviation: leaf: 1.23 , stem: 1.31 .

Correlation leaf and stem at 0.01:0.970 (**).

${ }^{z}$ Hort. group $=$ horticultural group.

${ }^{\mathrm{y}}$ Mean of three ratings of two replications.

Visual ratings on leaves and stems were scored at 7, 14, and $21 \mathrm{~d}$ postinoculation on the following scale: leaf, $1=0 \%$ of leaf area affected, $2=\geq 25 \%$ leaf area affected, $3=\geq 25 \% \leq 50 \%$ leaf area affected, $4=$ $\geq 50 \% \leq 75 \%$ leaf area affected, $5=\geq 75 \% \leq 100 \%$ leaf area affected; stem $1=$ no damage, $2=$ single lesion 1 to $10 \mathrm{~mm}$ long, or composite lesions 1 to $20 \mathrm{~mm}$, stem not girdled, $3=$ lesion 21 to $80 \mathrm{~mm}$ long or girdling of stem, $4=$ stem withered, and $5=$ seedling dead.

${ }^{x}$ Russian Fed. $=$ Russian Federation.

${ }^{\mathrm{w}}$ thins $=$ thin skin melon, belongs to the melo hort. group.

vthicks $=$ thick skin melon, belongs to the melo hort. group.

"NA = information not available.

$\mathrm{PI}$ - plant introduction.
Table 2. Mean stem scores for parental genotypes and susceptible control used in this study after inoculation with Didymella bryoniae spores.

\begin{tabular}{lcl}
\hline Parent & Mean scores $^{\mathrm{z}}$ & Rating \\
\hline Huanghemi $^{\mathrm{y}}$ & 4.6 & Susceptible \\
PI 268227 & 3.7 & Susceptible \\
PI 136170 & 3.8 & Susceptible \\
NSL 30032 & 3.1 & Susceptible \\
PI 157076 & 1.3 & Resistant \\
PI 420145 & 1.1 & Resistant \\
PI 323498 & 1.5 & Resistant \\
\hline
\end{tabular}

${ }^{\mathrm{z}}$ Mean of three ratings of two replications. Stem scores were based on a stem damage scale of $1-5$, in which $1=$ no damage, $2=$ a single lesion $1-10 \mathrm{~mm}$ long or coalesced lesions $1-20 \mathrm{~mm}$ long with no girdling of stem, $3=$ lesions $21-80 \mathrm{~mm}$ long, $4=$ lesions or girdling of the stem, $4=$ withered stem, and $5=$ dead seedling.

${ }^{\mathrm{y}}$ Huanghemi, susceptible control.

$\mathrm{PI}=$ plant introduction

observations support the hypothesis of a single dominant gene conditioning resistance to $D$. bryoniae in plant introduction 323498 .

\section{Discussion}

Our study largely confirmed previous reports that some accessions are resistant or susceptible (Table 1). However, we observed extreme cases in which several plant introductions previously rated highly resistant, e.g., plant introductions 482399 (Zimbabwe), 357791 (Yugoslavia), 182226 (Egypt), were rated highly susceptible in our work. Interestingly, three other plant introductions, 482397, 482395, and 482494, also from Zimbabwe previously rated $1.0,1.0$, and 1.07 (stem ratings) were only moderately resistant, $2.55,2.62$, and 2.24 , respectively, in our study. On the other extreme, we observed cases of, e.g., plant introductions 532829 (China), 500362 (Zambia), 185111 (Ghana), were rated highly resistant in our study. Differential response to D. bryoniae has been reported in cucumber (Van Der Meer et al., 1978; Wehner and Shetty, 2000; Wehner and St. Amand, 1993). It has been suggested that variation in response to GSB over environments may be the result of differences in fungal isolates (i.e., differences in virulence) or the result of isolate $x$ environment $\times$ plant interactions (Song et al., 2004). Our observations support this hypothesis and validate the need for retesting germplasm found to be highly resistant in one environment under varied environments, e.g., exposing the sources of resistance to existing and new isolates over different production areas before use in breeding programs.

We observed resistance in accessions not previously reported, e.g., in 'Jinguan' (stem rating of 1.0), a thin skin Chinese melon, Xin miZa9 (mean stem rating of 1.12), a hemi type Chinese melon, NJG1 (stem rating 1.3), and NJG6 (stem rating 1.2). NJG1 and NJG6 are local landraces collected from farms. Landrace accessions (ecotypes) have genes for breeding value. Landraces offer great potential for breeding because they are a result of many years of adaptation, breeding 
Table 3. Response of the susceptible melon (Cucumis melo) parents plant introductions 268227 and 136170, NSL 30032, the resistant parents plant introductions 157076, 420145, and 323498, their $F_{1}, F_{2}$ and reciprocal backcrosses when inoculated with Didymella bryoniae spores.

\begin{tabular}{|c|c|c|c|c|c|}
\hline \multirow[b]{2}{*}{ Pedigree $^{y}$} & \multirow[b]{2}{*}{ Generation $^{\mathrm{x}}$} & \multicolumn{2}{|c|}{ No. of plants ${ }^{z}$} & \multirow[b]{2}{*}{ Expected ratio (R:S) } & \multirow[b]{2}{*}{$P$ value $^{\mathrm{w}}$} \\
\hline & & $\mathrm{R}$ & $\mathrm{S}$ & & \\
\hline PI 268227 & $\mathrm{P}$ & 0 & 21 & $0: 1$ & - \\
\hline PI 136170 & $\mathrm{P}$ & 0 & 20 & $0: 1$ & - \\
\hline NSL 30032 & $\mathrm{P}$ & 0 & 24 & $0: 1$ & - \\
\hline PI 157076 & $\mathrm{P}$ & 66 & 1 & $1: 0$ & - \\
\hline PI 420145 & $\mathrm{P}$ & 68 & 0 & $1: 0$ & - \\
\hline PI 323498 & $\mathrm{P}$ & 43 & 1 & $1: 0$ & - \\
\hline PI $268227 \times$ PI 157076 & $\mathrm{~F}_{1}$ & 64 & 1 & $1: 0$ & - \\
\hline PI $268227 \times$ PI 157076 & $\mathrm{~F}_{2}$ & 74 & 30 & $3: 1$ & 0.35 \\
\hline$(227 \times 076) \times 227$ & $\mathrm{BC}_{\mathrm{s}}$ & 29 & 34 & $1: 1$ & 0.38 \\
\hline$(227 \times 076) \times 076$ & $\mathrm{BC}_{\mathrm{r}}$ & 104 & 0 & $1: 0$ & - \\
\hline PI $136170 \times$ PI 420145 & $\mathrm{~F}_{1}$ & 46 & 0 & $1: 0$ & - \\
\hline PI $136170 \times$ PI 420145 & $\mathrm{~F}_{2}$ & 69 & 20 & $3: 1$ & 0.27 \\
\hline$(170 \times 145) \times 170$ & $\mathrm{BC}_{\mathrm{s}}$ & 29 & 37 & $1: 1$ & 0.30 \\
\hline$(170 \times 145) \times 145$ & $\mathrm{BC}_{\mathrm{r}}$ & 68 & 0 & $1: 0$ & - \\
\hline NSL $30032 \times$ PI $323498 F_{1}$ & 50 & 0 & $1: 0$ & - & \\
\hline NSL $30032 \times$ PI $323498 F_{2}$ & 70 & 20 & $3: 1$ & 0.70 & \\
\hline$(032 \times 498) \times 032$ & $\mathrm{BC}_{\mathrm{s}}$ & 37 & 30 & $1: 1$ & 0.36 \\
\hline$(032 \times 498) \times 498$ & $\mathrm{BC}_{\mathrm{r}}$ & 63 & 0 & $1: 0$ & 一 \\
\hline
\end{tabular}

${ }^{\mathrm{z}} \mathrm{R}=$ resistant, $\mathrm{S}=$ susceptible.

${ }^{\mathrm{y}} 227=$ PI 268227, $076=$ PI 157076, $170=$ PI 136170, $145=$ PI 420145, $032=$ NSL 30032, $498=$ PI 323498.

${ }^{\mathrm{x}} \mathrm{P}=$ parent, $\mathrm{BC}_{\mathrm{s}}$, and $\mathrm{BC}_{\mathrm{r}}=$ backcross to susceptible and resistant parents, respectively.

${ }^{\mathrm{w}} P$ value at $\propto=0.05$.

$\mathrm{PI}=$ plant introduction.

work, and a high degree of genetic diversity that is largely untapped outside where they are grown. In the present study, we also identified a wild Cucumis species accession collected from the wild in the highlands of Kenya. This accession, coded JF1, was rated highly resistant with a symptom stem rating of 1.1, similar to data previously reported for plant introduction 140471. We are in the process of determining its value (e.g., crossability and horticultural characteristics) in relation to $C$. melo cultigens for future work and use.

Similar to JF1, the other wild relatives (e.g., plant introductions 196477, 299571, 364472 , C. figarei) were highly resistant both for stem and leaf scores. Our data are consistent with previous studies (Wehner and St. Amand, 1993; Zhang et al., 1997). Generally, the wild sources of resistance are not sexually compatible with cultivated melons; however, some success in interspecific hybridization in other cucurbits has been reported (Chen et al., 1997). Moreover, with advances in biotechnology, e.g., embryo rescue, protoplast fusion, wide crosses between cultivated melon and its wild relatives, may be foreseeable in the future.

Resistance in C. melo var. flexuous and inodorus accessions is rarely reported. Most germplasm reported for GSB resistance are from C. melo var agrestis (e.g., Sakata et al., 2000) or C. melo var. melo (Sowell, 1981; Sowell et al., 1966).

Stem resistance to GSB in melon has received more emphasis than leaf resistance (e.g., Frantz and Jahn, 2004; Sakata et al., 2000) probably because stem scores in different tests of a given accession are more highly correlated than leaf scores. Our observations, which need verification, were that higher leaf resistance was observed in germ- plasms with intermediate or lower stem resistance. Higher leaf resistance coupled with stem resistance would be a definite advantage. The high correlation between leaf and stem resistance in our work is consistent with the results of Zuniga et al. (1999).

The three accessions whose genetics of resistance we characterized flowered and fruited easily under our conditions; they have moderate-sized green fruits, larger than those of 140471, and could easily be deployed into commercial germplasms. There is still a need to characterize the genetics resistance in other melon accessions reported to be resistant to the GSB pathogen and to determine if these sources share the same or carry independent genetic factors for resistance. The allelic relationships among these plant introductions have not been reported. As a result of resource limitations, we did not determine allelic relationships among these accessions and between these accessions and those already determined, e.g., plant introductions 140471 and 482398; this will form the basis of our future work. Similar to our result, Zuniga et al. (1999) also determined resistance in plant introduction 157082 was monogenic dominant. Plant introduction 157082 and plant introduction 157076 are both from China. However, Zuniga et al. (1999) went further and showed that the gene in plant introduction 157082 was not linked to that in plant introduction 140471. The gene conferring resistance in plant introduction 157082 was named Gsb-3 (Frantz and Jahn, 2004); it will be interesting to determine the allelic relationship between this gene and that in plant introduction 157076. Both genotypes are C. melo var. melo.

In conclusion, it is important to screen melon cultigens against $D$. bryoniae over varied environments to assure their univer- sality of resistance and subsequent use in breeding programs. Equally important is the need to characterize the mode of inheritance in the sources of resistance to cut down on the costs of trial and error, crossing, backcrossing, evaluation and reevaluation, and selection from the progenies.

\section{Literature Cited}

Bruton, B.D. 1998. Soil borne diseases in Cucurbitaceae: Pathogen virulence and host resistance, p. 143-166. In: J. McCreight (ed.). Cucurbitaceae 98-Evaluation and enhancement of Cucurbit germplasm. American Society of Horticultural Science Press, Alexandria, Va.

Chen, J.F., J.E. Staub, Y. Toshiro, S. Issbiki, and S. Miyazaki. 1997. Successful interspecific hybridization between Cucumis sativus L. and Cucumis hystrix Chakr. Euphytica. 96: 413-419.

Crosby, K.M., M.E. Miller, and D.W. Wolff. 2002. Screening plant introductions of Cucumis melo for resistance to Monosporascus cannonballus, p. 188-191. In: D.N. Maynard (ed.). Cucubitaceae 2002, American Society of Horticultural Science Press, Alexandria, Va.

Frantz, J.D. and M.M. Jahn. 2004. Five independent loci each control monogenic resistance to gummy stem blight in melon (Cucumis melo L.). Theor. Appl. Genet. 108:1033-1038.

Gusmini, G., T.L. Ellington, and T.C. Wehner. 2003. Mass production of gummy stem blight spores for resistance screening. Cucurbit Gen. Coop. Rpt. 26:26-30.

Gusmini, G. and T.C. Wehner. 2002. Correlation of ratings for resistance to gummy stem blight in watermelon. In: D.N. Maynard (ed.). Cucubitaceae 2002, p. 199-205. American Society of Horticultural Science Press, Alexandria, Va.

Kato, T., K. Suzuki, J.K. Takahashi, and K. Kamoshita. 1984. Negatively correlated crossresistance between benzimidazole fungicides and methyl N-(3,5-dichlorophenyl) carbamate. J. Pesticide Sci. 9:489-495.

Keinath, A.P., F.W. Farnham, and T.A. Zitter. 1995. Morphological, pathological, and genetic differentiation of Didymella bryoniae and Phoma spp. Isolated from cucurbits. Phytopathol. 85:364-369.

Keinath, A.P. and T.A. Zitter. 1998. Resistance to benomyl and thiophanate-methyl in Didymella bryoniae from South Carolina and New York. Plant Dis. 82:479-484.

Kwon, M.K., J.R. Hong, H.J. Sun, K.Y. Sung, B.H Cho, and K.C. Kim. 1997. Standardization of a mass production technique for pycnidiospores of Didymella bryoniae, gummy stem blight fungus of cucurbits. Korean J. Plant Pathol. 13:105-112.

Malathrokis, N.E. and D.J. Vokalounakis. 1983. Resistance to benzinidazole fungicides in gummy stem blight pathogen Didymella bryoniae on cucurbits. Plant Pathol. 32:395-399.

McCreight, J.D. 2002. Reactions of 20 melon cultigens to powdery mildew race 2 U.S. Cucubitaceae, p. 72-77. In: D.N. Maynard (ed.). Cucubitaceae 2002. American Society of Horticultural Science Press, Alexandria, Va.

McGrath, D.J., L. Vawdrey, and O. Walker. 1993. Resistance to gummy stem blight in muskmelon. HortScience 28:930-931.

Norton, J.D. 1971. Gulfcoast-A sweet cantaloupe for the produce chain store market. Alabama Agr. Expt. Sta. Lflt. 82.

Norton, J.D. 1972. Chilton, a high quality fruit for the commercial market. Alabama Agr. Expt. Sta. Lflt. 84. 
Norton, J.D. and R.D. Cosper. 1989. AC-70-154, a gummy stem blight resistant muskmelon breeding line. HortScience 24:709-711.

Norton, J.D., R.D. Cosper, D.A. Smith, and K.S. Rymal. 1985. Aurora-A high quality disease resistant cantaloupe. Alabama Agr. Expt. Sta. Circ. 278.

Pitrat, M., C. Dogimont, and M. Bardin. 1998. Resistance to fungal diseases of foliage in melon. Cucurbitaceae, p. 167-173. In: J. McCreight (ed.). Cucurbitaceae '98-Evaluation and enhancement of Cucurbit germplasm. American Society of Horticultural Science Press, Alexandria, Va.

Prasad, K. and J.D. Norton. 1967. Inheritance of resistance to Mycosphaerella citrulina in muskmelon. J. Amer. Soc. Hort. Sci. 91:396-400.

Sakata, Y., T. Wako, M. Sugiyama, and M. Morishita. 2000. Screening melons for resistance to gummy stem blight. Acta Hort. 510:171-177.

Sitterly, W.R. and A.P. Keinath. 1996. Gummy stem blight, p. 27-28. In: T.A. Zitter, D.L. Hopkins, and C. Thomas (eds.). Compedium of cucurbit diseases. APS Press, St. Paul, Minn.

Song, R., G. Gusmini, and T.C. Wehner. 2004. A summary of eleven preliminary studies of greenhouse and field testing methods for resistance to gummy stem blight in melon, p. 301305. In: A. Lebeda and H.S. Paris (eds.). Progress in Cucurbit Genetics and Breeding Research. Palacky' University in Olomouc, Czech Republic.

Sowell, G., Jr. 1981. Additional sources of resistance to gummy stem blight of muskmelon. Plant Dis. 65:253-254.
Sowell, G., Jr., K. Prasad, and J.D. Norton. 1966. Resistance of Cucumis melo introductions to Mycosphaerella citrullina. Plant Dis. Rpt. 50:661-663.

St. Amand, P.C. and T.C. Wehner. 1991. Crop loss to 14 diseases of cucumber in North Carolina from 1983 to 1988. Cucurbit Genet. Coop. Rpt. $14: 15-17$.

Takada, K. 1983. Breeding and characteristics of disease-resistant varieties (lines 'Ano No. 1, No. 2 and No. 3'). Bull. Veg. Ornam. Crops Res. Series A. 11:1-22.

Tsutsumi, C.Y. and N. da Silva. 2004. Screening of melon populations for resistance to Didymella bryoniae. Braz. Arch. Biol. Technol. 47: 171-177.

Tullu, A., L. Buchwaldt, T. Warkentin, B. Taran, and A. Vandenberg. 2002. Genetics of resistance to anthracnose and identification of AFLP and RAPD markers linked to the resistance gene in PI 320937 germplasm of lentil (Lens culinaris Mediks). TAG. 106: 428-434.

Van Der Meer, Q.P., J.L. Van Bemekon, and A.C. Van Der Giessen. 1978. Gummy stem blight resistance of cucumbers (Cucumis sativus L.). Euphytica 27:661-664.

van Steekelenburg, N.A.M. 1985. Influence of time of transmission from night to day temperature regimes in incidence of Didymella bryoniae and influence of disease on growth and yield of glasshouse cucumbers. Neth. J. Plant Pathol. 91:225-233.

Vokalounakis, D.J. 1993. Inheritance and genetic linkage of fusarium wilt (Fusarium oxysporium f. sp. cucumerinum race 1) and scab (Cladisporium cucumerinum) resistance genes in cucumber (Cucumis sativus). Ann. Appl. Biol. 123:359-365.

Vokalounakis, D.J. 1995. Inheritance and linkage of resistance in cucumber line SMR-18 to races 1 and 2 of Fusarium oxysporium $f$. sp. cucumerinum. Plant Pathol. 44:169-172.

Wako, T., Y. Sakata, M. Sugiyama, T. Ohara, D. Ishiuji, A. Kojima, and S. Nishimura. 2002. Identification of melon accessions resistant to gummy stem blight and genetic analysis of the resistance using an efficient technique for seedling test. Acta Hort. 588:161-164.

Wehner, T.C. and N.V. Shetty. 2000. Screening the cucumber germplasm collection for resistance to gummy stem blight in North Carolina field tests. HortScience 35:1132-1140.

Wehner, T.C. and P.C. St. Amand. 1993. Field tests for cucumber resistance to gummy stem blight in North Carolina. HortScience 28: 327-329.

Zhang, Y., M.M. Kyle, K. Anagnostou, and T.A Zitter. 1997. Screening melon (Cucumis melo) for resistance to gummy stem blight in the greenhouse and field. HortScience 32:117-121.

Zitter, T.A. and M.M. Kyle. 1992. Impact of powdery mildew and gummy stem blight on collapse of pumpkin (Cucurbita pepo L.). Cucurb. Genet. Coop. Rpt. 15:93-96.

Zuniga, T.L., J.P. Jantz, T.A. Zitter, and M.M. Jahn. 1999. Monogenic dominant resistance to gummy stem blight in two melon (Cucumis melo) accessions. Plant Dis. 83: 1105-1107. 